\title{
Correction to: Bonobo and Chimpanzee
}

\section{Correction to:}

T. Furuichi, Bonobo and Chimpanzee,

Primatology Monographs, https://doi.org/10.1007/978-981-13-8059-4

The book was inadvertently published with the wrong figure legend for Fig. 1.3 in Chap. 1. This has now been corrected.

The book was inadvertently published with the wrong figure caption for Fig. 4.2 in Chap. 4. This has now been corrected.

The book was inadvertently published without including the reference number in the figure caption of Fig. 5.1 in Chap. 5. This has now been corrected.

The updated online versions of the chapters can be found at https://doi.org/10.1007/978-981-13-8059-4_1

https://doi.org/10.1007/978-981-13-8059-4_4

https://doi.org/10.1007/978-981-13-8059-4_5 